\title{
Sol-gel enhanced mesoporous Cu-Ce-Zr catalyst for toluene oxidation
}

\section{Running Kang, Xiaolin Wei, Huixin Li, Feng Bin, Ruozhu Zhao, Qinglan Hao \& Baojuan Dou}

To cite this article: Running Kang, Xiaolin Wei, Huixin Li, Feng Bin, Ruozhu Zhao, Qinglan Hao \& Baojuan Dou (2017): Sol-gel enhanced mesoporous Cu-Ce-Zr catalyst for toluene oxidation, Combustion Science and Technology, DOI: 10.1080/00102202.2017.1416360

To link to this article: https://doi.org/10.1080/00102202.2017.1416360

Accepted author version posted online: 13

Dec 2017.

Published online: 26 Feb 2018.

Submit your article to this journal $₫$

山 Article views: 13

Q View related articles ¿ك

View Crossmark data $[\pi$ 


\title{
Sol-gel enhanced mesoporous $\mathrm{Cu}-\mathrm{Ce}-\mathrm{Zr}$ catalyst for toluene oxidation
}

\author{
Running Kang ${ }^{\mathrm{a}, \mathrm{b}}$, Xiaolin Wei ${ }^{\mathrm{a}, \mathrm{c}}$, Huixin $\mathrm{Li}^{\mathrm{a}, \mathrm{c}}$, Feng Bina, Ruozhu Zhao ${ }^{\mathrm{d}}$, Qinglan Hao ${ }^{\mathrm{d}}$, \\ and Baojuan Dou ${ }^{d}$
}

aState Key Laboratory of High-Temperature Gas Dynamics, Institute of Mechanics, Chinese Academy of Sciences, Beijing, PR China; ${ }^{\mathrm{b} C o l l e g e}$ of Metallurgy and Energy, North China University of Science and Technology, Tangshan, PR China; 'School of Engineering Science, University of Chinese Academy of Sciences, Beijing, PR China; ${ }^{\mathrm{d}}$ College of Environmental Sciences, Tianjin University of Science \& Technology, Tianjin, PR China

\begin{abstract}
The bulk-phase $\mathrm{Cu}$-Ce-Zr catalyst BP-gel was prepared by the solgel method and investigated for the oxidation of toluene in a fixed-bed reactor. For comparison, other bulk-phase catalysts (thermal decomposition (BP-td), solid-state reaction (BP-sr)) and supported catalysts (incipient wetness impregnation (S-iwi), saturated impregnation (S-si)) were tested. The results showed that the catalytic activities were in the following order: BP-gel $>\mathrm{S}$-si $>\mathrm{S}$ iwi>BP-td >BP-sr. The BP-gel catalyst, which has a mesoporous structure, is beneficial for the mass transfer of reactant molecules. The thermal stability of the BP-gel catalyst was improved by the introduction of $\mathrm{ZrO}_{2}$. Bulk $\mathrm{CuO}$ in the catalysts reduced their activity because the synergetic effect between $\mathrm{CuO}$ and $\mathrm{CeO}_{2}$ decreased. The low-temperature reducibility, large pore sizes, rich oxygen vacancies, and active oxygen species contributed to the highest activity of the BP-gel, with a $\mathrm{T}_{90}$ as low as $219^{\circ} \mathrm{C}$, and no deactivation was observed during the $72 \mathrm{~h}$ stability test at the set temperature.
\end{abstract}

\section{ARTICLE HISTORY}

Received 5 September 2017

Revised 9 November 2017

Accepted 8 December 2017

\section{KEY WORDS}

Cu-Ce-Zr Catalyst; Catalytic Oxidation; Preparation

Method; Toluene

\section{Introduction}

Currently, volatile organic compounds (VOCs) from natural and industrial sources are considered a main cause of current serious environmental problems. Their toxic nature leads to serious air pollution, such as photochemical smog, haze, and the production of ground-level ozone (He et al., 2015a; He et al., 2014; Kuo et al., 2014). Hence, environmental air quality standards have been greatly increased and strictly enforced, which has led to much attention to the development of efficient methods for VOC abatement (Gutiérrez-Ortiz et al., 2006).

Catalytic oxidation is emerging as an environmentally friendly technique for the degradation of VOCs (Tang et al., 2015a, Wang et al., 2015a). Typical catalysts employed for VOC oxidation are multi-component metal oxides, since they have a lower cost than noble metal catalysts, although the former exhibit activity at moderate temperature (Li et al., 2016, Lu et al., 2015). It is well known that the structure-activity 
relationship of metal oxides is determined by traditional preparation methods, such as co-precipitation, impregnation, and hydrothermal synthesis, but unfortunately, such bulk-phase catalysts, which are obtained with small pore size, always limit the enhancement of their activity ( $\mathrm{Hu}$ et al., 2009). By contrast, the sol-gel method can be successfully employed to synthesize metal oxides with relatively broad pore size distributions and large pore volumes. In this case, the unique mesoporous structure is highly beneficial for the migration and diffusion of reactant molecules during reaction. Previously, a Mn-Ce composite oxide with a mesoporous structure, prepared by the sol-gel method, was successfully applied to benzene oxidation. Although the lowtemperature reducibility, broad pore size distribution and rich adsorbed surface oxygen species greatly contribute to the activity toward benzene oxidation, the stability is still unsatisfactory, as the activity decreases from $100 \%$ to $92 \%$ after $12 \mathrm{~h}$ at $275^{\circ} \mathrm{C}$ (Tang et al., 2015b).

Mixed metal oxide catalysts containing copper, cerium and zirconium have attracted great interest in low-temperature VOC oxidation (Bin et al., 2014). In these catalysts, $\mathrm{CuO}$ is considered to be the active component due to their excellent reducibility (Zhang et al., 2015a). $\mathrm{CeO}_{2}$ not only promotes the dispersion of active copper species but provides a large oxygen storage-release capacity owing to the $\mathrm{Ce}^{4+}-\mathrm{Ce}^{3+}$ redox couple in the cubic fluorite structure ( $\mathrm{Zhou}$ et al., 2014). Although $\mathrm{ZrO}_{2}$ cannot contribute to the catalytic activity directly, zirconium entering the $\mathrm{CeO}_{2}$ lattice has a strong effect on its thermal stability and thus provides the possibility to improve the catalytic performance through the formation of a Ce-Zr solid solution (Moretti et al., 2017; Riva et al., 2009).

In this study, a bulk-phase $\mathrm{CuCe}_{0.75} \mathrm{Zr}_{0.25} \mathrm{O}_{\mathrm{y}}$ catalyst with a mesoporous structure and highly dispersed $\mathrm{CuO}$ was synthesized using the sol-gel method. Here, the ratio of $\mathrm{Cu}: \mathrm{Ce}: \mathrm{Zr}$ was set at 1:0.75:0.25 based on our previous study, where $\mathrm{CuCe}_{0.75} \mathrm{Zr}_{0.25} \mathrm{O}_{\mathrm{y}}$ mixed oxides formed on $\mathrm{ZSM}-5$ substrates showed higher activities for the catalytic removal of ethyl acetate than other ratios because the copper-ceria synergism improves the excellent redox capability and the ceria-zirconium solid solution has a good oxygen storage capacity under these conditions (Dou et al., 2011). However, the adsorption, desorption and diffusion of VOCs were restricted by the microporous ZSM-5, increasing the possibility of secondary reactions and coke formation. For comparison, bulk-phase $\mathrm{CuCe}_{0.75} \mathrm{Zr}_{0.25} \mathrm{O}_{\mathrm{y}}$ catalysts were synthesized by typical methods, e.g., thermal decomposition and solid-state reaction methods, and supported $\mathrm{CuCe}_{0.75} \mathrm{Zr}_{0.25} \mathrm{O}_{\mathrm{y}} / \mathrm{H}-\mathrm{ZSM}-5$ catalysts with the same composition of $\mathrm{CuCe}_{0.75} \mathrm{Zr}_{0.25} \mathrm{O}_{\mathrm{y}}$ were also prepared by incipient wetness impregnation and saturated impregnation.

The aim of this study is to determine the influence of the pore size of the bulk-phase CuO$\mathrm{CeO}_{2}-\mathrm{ZrO}_{2}$ catalysts on the oxygen vacancies in the catalysts, the migration and diffusion of VOCs, the catalytic activity, and the stability. The catalytic activity was evaluated toward the oxidation of toluene, which is a typical aromatic hydrocarbon extensively applied in industrial processes. Combined with characterization techniques such as Brunauer-Emmett-Teller (BET) analysis, X-ray diffraction (XRD), temperature-programmed desorption of oxygen $\left(\mathrm{O}_{2}\right.$-TPD), temperature-programmed desorption of ammonia $\left(\mathrm{NH}_{3}-\mathrm{TPD}\right)$, and temperature-programmed hydrogen reduction $\left(\mathrm{H}_{2}\right.$-TPR), the relationship between the physico-chemical properties, the reaction mechanism and the activity for toluene oxidation over the catalysts was investigated in detail. 


\section{Experimental}

\section{Catalyst preparation}

$\mathrm{Cu}\left(\mathrm{NO}_{3}\right)_{2} \cdot 3 \mathrm{H}_{2} \mathrm{O}, \mathrm{Ce}\left(\mathrm{NO}_{3}\right)_{3} \cdot 6 \mathrm{H}_{2} \mathrm{O}$ and $\mathrm{Zr}\left(\mathrm{NO}_{3}\right)_{4} \cdot 5 \mathrm{H}_{2} \mathrm{O}$ (A.R.) were purchased from Jiangtian Co., Ltd., Tianjin, P. R. China. Deionized water was used in all experimental processes. H-ZSM-5 with an atomic Si/Al ratio of 25 was supplied by Nankai University, Tianjin, P. R. China.

\section{Bulk-phase cuce ${ }_{0.75} \mathrm{Zr}_{0.25} \mathrm{O}_{\mathrm{y}}$ catalyst preparation}

Bulk-phase $\mathrm{CuCe}_{0.75} \mathrm{Zr}_{0.25} \mathrm{O}_{\mathrm{y}}$ catalysts were prepared by three methods, namely, sol-gel, thermal decomposition and solid-state reaction. The molar ratio of $\mathrm{Cu} /(\mathrm{Ce}+\mathrm{Zr})$ in the $\mathrm{CuCe}_{0.75} \mathrm{Zr}_{0.25} \mathrm{O}_{\mathrm{y}}$ catalysts was controlled at $1: 1$. The molar content of the $\mathrm{CuO}, \mathrm{CeO}_{2}$ and $\mathrm{ZrO}_{2}$ in prepared catalysts was also detected by XRF.

(1) Sol-gel method (BP-gel)

$\mathrm{Cu}\left(\mathrm{NO}_{3}\right)_{2} \cdot 3 \mathrm{H}_{2} \mathrm{O}, \mathrm{Ce}\left(\mathrm{NO}_{3}\right)_{3} \cdot 6 \mathrm{H}_{2} \mathrm{O}$ and $\mathrm{Zr}\left(\mathrm{NO}_{3}\right)_{4} \cdot 5 \mathrm{H}_{2} \mathrm{O}$ in a 4:3:1 molar ratio were dissolved in $70 \mathrm{~mL}$ of ethanol at $80^{\circ} \mathrm{C}$. Then, $0.24 \mathrm{~mol} / \mathrm{L}$ of oxalic acid solution was added quickly to the above nitrate solution with stirring until a gel was formed. The gel was continuously stirred and kept at $80^{\circ} \mathrm{C}$ for $12 \mathrm{~h}$. After aging at room temperature for approximately $48 \mathrm{~h}$, the gel was dried at $80^{\circ} \mathrm{C}$ for $12 \mathrm{~h}$ and calcined at $550^{\circ} \mathrm{C}$ for another $2 \mathrm{~h}$.

(2) Thermal decomposition method (BP-td)

Appropriate amounts of $\mathrm{Cu}\left(\mathrm{NO}_{3}\right)_{2} \cdot 3 \mathrm{H}_{2} \mathrm{O}, \mathrm{Ce}\left(\mathrm{NO}_{3}\right)_{3} \cdot 6 \mathrm{H}_{2} \mathrm{O}$ and $\mathrm{Zr}\left(\mathrm{NO}_{3}\right)_{4} \cdot 5 \mathrm{H}_{2} \mathrm{O}$ were dissolved in $350 \mathrm{~mL}$ of deionized water at room temperature. The mixed solution was first evaporated to dryness at $80^{\circ} \mathrm{C}$, and then, the mixture was further kept at $105^{\circ} \mathrm{C}$ for $24 \mathrm{~h}$ and calcined at $550^{\circ} \mathrm{C}$ for $2 \mathrm{~h}$.

(3) Solid-state reaction (BP-sr)

$\mathrm{Cu}\left(\mathrm{NO}_{3}\right)_{2} \cdot 3 \mathrm{H}_{2} \mathrm{O}, \mathrm{Ce}\left(\mathrm{NO}_{3}\right)_{3} \cdot 6 \mathrm{H}_{2} \mathrm{O}$ and $\mathrm{Zr}\left(\mathrm{NO}_{3}\right)_{4} \cdot 5 \mathrm{H}_{2} \mathrm{O}$ in the desired molar ratio were first milled using mechanical mixing for $10 \mathrm{~min}$, and then, the mixed sample was calcined in air at $550^{\circ} \mathrm{C}$ for $2 \mathrm{~h}$ before use.

\section{Supported Cuce ${ }_{0.75} \mathrm{Zr}_{0.25} \mathrm{O}_{\mathrm{y}} / \mathrm{H}-\mathrm{ZSM}-5$ catalyst preparation}

Supported $\mathrm{CuCe}_{0.75} \mathrm{Zr}_{0.25} \mathrm{O}_{\mathrm{y}} / \mathrm{H}-\mathrm{ZSM}-5$ catalysts were prepared by saturated impregnation and incipient impregnation. The copper contents of the $\mathrm{CuCe}_{0.75} \mathrm{Zr}_{0.25} \mathrm{O}_{\mathrm{y}} / \mathrm{H}-\mathrm{ZSM}-5$ catalysts were fixed at $4 \mathrm{wt} \%$, and the molar ratio of $\mathrm{Cu} /(\mathrm{Ce}+\mathrm{Zr})$ was $1: 1$.

(1) Saturated impregnation (S-si)

The synthesis of the supported catalyst prepared by saturated impregnation has been provided previously (Dou et al., 2011). In brief, appropriate amounts of copper acetate, zirconium, and cerium nitrate were dissolved in deionized water and mixed with $20 \mathrm{~g}$ 
H-ZSM-5 powder at the temperature of $70{ }^{\circ} \mathrm{C}$ until the water evaporated. Then, the resulting precursor was dried at $105^{\circ} \mathrm{C}$ for $24 \mathrm{~h}$ in air and calcined at $550^{\circ} \mathrm{C}$ for $4 \mathrm{~h}$.

(2) Incipient impregnation (S-iwi)

Desired amounts of copper acetate, zirconium, and cerium nitrate were dissolved in $25 \mathrm{~mL}$ of deionized water. Then, $20 \mathrm{~g}$ of H-ZSM- 5 was added to the solution and stirred. The resulting mixture was kept at $30^{\circ} \mathrm{C}$ for $12 \mathrm{~h}$. Finally, the precursor was dried at $105^{\circ} \mathrm{C}$ for $12 \mathrm{~h}$ and calcined at $550^{\circ} \mathrm{C}$ for $4 \mathrm{~h}$ under ambient atmosphere.

\section{Catalyst characterization}

$\mathrm{N}_{2}$ adsorption-desorption isotherms were collected at $-196^{\circ} \mathrm{C}$ using an Autosorb-Iq-MP instrument (Quantachrome). The sample was degassed at $300^{\circ} \mathrm{C}$ for more than $4 \mathrm{~h}$ before measurement. The specific surface area of the samples was calculated following the Brunauer-Emmett-Teller (BET) method. The average pore size was obtained by the Barrett-Joyner-Halenda (BJH) method and non-local density functional theory (NLDFT) modeling. The X-ray diffraction (XRD) analysis was performed on an XD-3automatic (PERSEE) with $\mathrm{Cu} \mathrm{Ka}$ radiation. The patterns were collected over a $2 \theta$ range of $5^{\circ}$ to $80^{\circ}$ with a step size of $0.02^{\circ}$ at a scanning rate of $4^{\circ} / \mathrm{min}$. Temperature-programmed reduction (TPR) experiments were carried out using a PCA-140 instrument (Bolider) equipped with a thermal conductivity detector (TCD). First, $200 \mathrm{mg}$ of sample was pretreated in an $\mathrm{Ar}$ stream at $500^{\circ} \mathrm{C}$ for $1 \mathrm{~h}$ at a rate of $20^{\circ} \mathrm{C} / \mathrm{min}$ and then cooled to room temperature. After that, a reduction gas of $5 \% \mathrm{H}_{2} / \mathrm{Ar}$ was introduced at a flow rate of $50 \mathrm{~mL} / \mathrm{min}$. The sample was heated from room temperature to $800^{\circ} \mathrm{C}$ at a heating rate of $10{ }^{\circ} \mathrm{C} / \mathrm{min}$. The temperature-programmed desorption of oxygen $\left(\mathrm{O}_{2}\right.$-TPD) was recorded on the same PCA-140 instrument. For this, $200 \mathrm{mg}$ of fresh catalyst was used, and then, $\mathrm{O}_{2}$ was adsorbed at $550^{\circ} \mathrm{C}$ for $30 \mathrm{~min}$, cooled to $30^{\circ} \mathrm{C}$, and then exposed to $\mathrm{Ar}$ $(50 \mathrm{~mL} / \mathrm{min})$; the reactor was heated at a rate of $10^{\circ} \mathrm{C} / \mathrm{min}$ until reaching $950^{\circ} \mathrm{C}$. Temperature-programmed desorption of ammonia $\left(\mathrm{NH}_{3}-\mathrm{TPD}\right)$ experiments were used to measure the surface acidity of the catalysts. First, $200 \mathrm{mg}$ of sample was pretreated in an Ar stream $(50 \mathrm{~mL} / \mathrm{min})$ at $500^{\circ} \mathrm{C}$ for $1 \mathrm{~h}$ at a rate of $20^{\circ} \mathrm{C} / \mathrm{min}$ and then cooled to room temperature. Second, the catalyst was exposed to a flow of $5 \% \mathrm{NH}_{3} / \mathrm{Ar}(50 \mathrm{~mL} / \mathrm{min})$ at $100^{\circ} \mathrm{C}$ for $30 \mathrm{~min}$ to reach saturation. Finally, the $\mathrm{NH}_{3}$ desorption profile was recorded from $100^{\circ} \mathrm{C}$ to $800^{\circ} \mathrm{C}$ under Ar stream flow $\left(50 \mathrm{~mL} / \mathrm{min}\right.$, at a heating rate of $\left.10^{\circ} \mathrm{C} / \mathrm{min}\right)$.

\section{Catalytic activity measurement}

Toluene was selected as a probe pollutant to examine the removal effectiveness of the catalysts, and the toluene oxidation reaction was performed in a fixed-bed reactor, in which approximately $0.8 \mathrm{~g}$ of catalyst (20-40 mesh) was loaded. The reaction temperature was monitored by a thermocouple located inside the catalyst bed. The reaction feed is $1500 \mathrm{ppm}$ of toluene in dry air with a total gas flow of $400 \mathrm{~mL} / \mathrm{min}$ and space velocity (SV) of $24,000 \mathrm{~h}^{-1}$. The reactor was heated from room temperature to $110^{\circ} \mathrm{C}$ at a heating rate of $1^{\circ} \mathrm{C} / \mathrm{min}$ in flowing air and held at this temperature for $30 \mathrm{~min}$ before catalytic activity testing. The compositions at the inlet and outlet of the reactor were analyzed using 
a gas chromatograph (GC-7900, Shanghai Tianmei Co., China) with a flame ionization detector (FID, HP-5) for the quantitative analysis of toluene, and a TCD (TDX-01) was used for the quantitative analysis of $\mathrm{CO}_{2}$. The conversion of toluene was calculated based on the concentration differences between the inlet and outlet gases. The selectivity toward $\mathrm{CO}_{2}$ was calculated as a percentage of the outlet concentration of $\mathrm{CO}_{2}$ to the total content of toluene converted to $\mathrm{CO}_{2}$.

\section{Results and discussion}

\section{Catalyst textural properties}

The $\mathrm{N}_{2}$ adsorption-desorption isotherms and corresponding pore size distribution curves of the bulk-phase $\mathrm{CuCe}_{0.75} \mathrm{Zr}_{0.25} \mathrm{O}_{\mathrm{y}}$ catalysts and supported $\mathrm{CuCe}_{0.75} \mathrm{Zr}_{0.25} \mathrm{O}_{\mathrm{y}} / \mathrm{H}-\mathrm{ZSM}-5$ catalysts are shown in Figure 1. It is clearly seen from Figure 1 (a) that the supported S-iwi and S-si catalysts exhibit a representative type I isotherm according to the IUPAC classification. There are two curves with the same color and markers for each catalyst, which correspond to the $\mathrm{N}_{2}$ adsorption-desorption isotherm. The pore size distributions can be calculated according to the hysteresis loop formed by the two curves for each catalyst. When the relative pressure is less than 0.02 , the increase in the adsorbed amount indicates that the volume is filled with micropores belonging to the H-ZSM-5 structure (Ge et al., 2015). By contrast, BP-td and BP-sr show type IV isotherms with a H3-type hysteresis loop, suggesting the presence of mesopores. The amount of adsorbed $\mathrm{N}_{2}$ increases significantly when the relative pressure is close to 1 , which is due to volume filling of the interparticle spaces (He et al., 2015a). With respect to BP-gel, typical type IV adsorption isotherms and a steep capillary condensation step with $\mathrm{H}_{2}$-type hysteresis loop are clearly observed in Figure 1 (a), indicating the formation of worm-like mesopores in the catalyst. It is further demonstrated
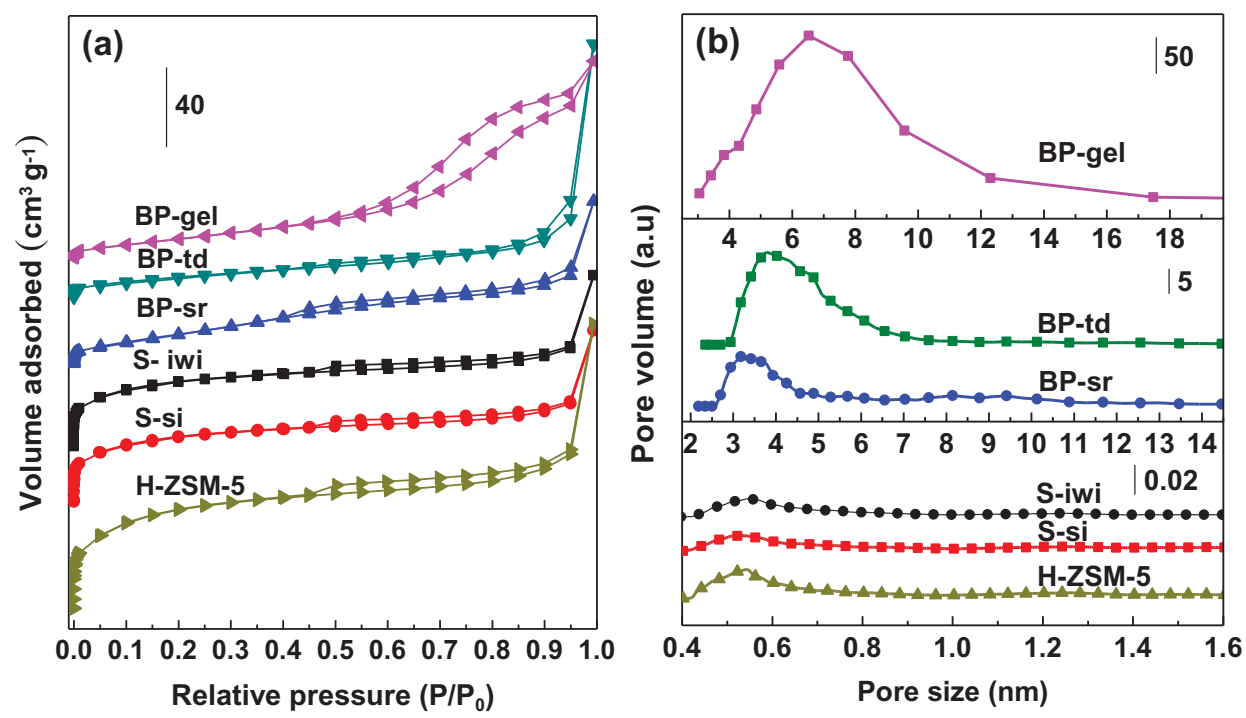

Figure 1. $\mathrm{N}_{2}$ adsorption and desorption isotherms (a) and pore size distributions (b) of $\mathrm{CuCe}_{0.75} \mathrm{Zr}_{0.25} \mathrm{O}_{\mathrm{y}}$ and $\mathrm{CuCe}_{0.75} \mathrm{Zr}_{0.25} \mathrm{O}_{\mathrm{y}} / \mathrm{H}-\mathrm{ZSM}-5$ catalysts. 
that mesopores are dominant in the BP-gel by comparing the pore size distributions in Figure 1 (b), while the pore size distribution curves of S-iwi and S-si present one single narrow peak in the microporous range at ca. $0.4-0.65 \mathrm{~nm}$.

Table 1 displays the BET surface area, pore volume, and mean pore diameter of the catalysts. The pore sizes of S-iwi $(0.37 \mathrm{~nm})$ and S-si $(0.53 \mathrm{~nm})$ are much lower than those of BP-gel $(6.52 \mathrm{~nm})$, BP-td $(3.54 \mathrm{~nm})$, and BP-sr $(3.78 \mathrm{~nm})$. Furthermore, the $\mathrm{S}_{\mathrm{BET}}$ of the supported catalysts $\left(295-339 \mathrm{~m}^{2} / \mathrm{g}\right)$ are observed to be much higher than those of the bulk-phase catalysts $\left(44-62 \mathrm{~m}^{2} / \mathrm{g}\right)$ owing to the high surface area of the H-ZSM-5 support. The pore volumes are determined to follow the sequence $\mathrm{S}$-si $>\mathrm{S}$-iwi $>\mathrm{BP}$-td $>\mathrm{BP}$-gel $>\mathrm{BP}$-sr. The BET surface area and total pore volume of the supported S-si and S-iwi catalysts are observed to be lower than those of H-ZSM-5 due to the presence of $\mathrm{Cu}-\mathrm{Ce}-\mathrm{Zr}$ ternary oxides in the pores of H-ZSM-5 (Chen et al., 2014).

\section{Crystal structure of the catalysts}

Figure 2 presents the XRD patterns of the catalysts, and the lattice parameters of the BP$\mathrm{td}$, BP-gel and BP-sr catalysts are summarized in Table 1. It is clearly seen that the characteristic diffraction peaks are quite different between the bulk-phase catalysts and the supported catalysts. For the supported catalysts S-si and S-iwi, only the characteristic diffraction peaks of H-ZSM-5 are observed, which is indicative of copper, cerium, and zirconium oxides existing in the nanometer range and their uniform distribution on the H-ZSM-5 surface (Bin et al., 2014), while the supported catalysts maintain their microstructures. For the bulk-phase catalysts of BP-td, BP-gel and BP-sr, the characteristic diffraction peaks of $\mathrm{CeO}_{2}$ are observed to be weaker and broader than those of pure $\mathrm{CeO}_{2}$. The peak of $\mathrm{CeO}_{2}$ at $2 \theta=28.2^{\circ}$ is clearly seen to shift to a higher $2 \theta$ value, while the peaks of $\mathrm{CeO}_{2}$ at $2 \theta>60^{\circ}$ in all the bulk-phase catalysts disappear. In Table 1 , the lattice parameters of the BP-td, BP-gel and BP-sr catalysts decrease slightly compared with those of pure $\mathrm{CeO}_{2}$, suggesting the formation of lattice defects and oxygen vacancies due to $\mathrm{Cu}^{2+}$ ion $(0.072 \mathrm{~nm})$ and $\mathrm{Zr}^{4+}$ ion $(0.084 \mathrm{~nm})$ incorporation into the $\mathrm{CeO}_{2}$ lattice. The results are also consistent with previously reported work (Jia et al., 2012; Luo et al., 2007). The presence of lattice defects and oxygen vacancies in the catalyst can greatly contribute to the formation of absorbed oxygen. The active oxygen species resulting from the adsorbed oxygen can subsequently promote the activity of the catalytic oxidation of VOCs (Hu et al., 2009). Furthermore, two weak diffraction peaks corresponding to bulk $\mathrm{CuO}$ in the BP-gel and BP-td catalysts are clearly observed, suggesting the presence of $\mathrm{CuO}$ species in the aggregation state.

Table 1. Textural properties of $\mathrm{CuCe}_{0.75} \mathrm{Zr}_{0.25} \mathrm{O}_{\mathrm{y}}$ and $\mathrm{CuCe}_{0.75} \mathrm{Zr}_{0.25} \mathrm{O}_{\mathrm{y}} / \mathrm{H}-\mathrm{ZSM}-5$ catalysts.

\begin{tabular}{lcccc}
\hline Samples & Surface area $\left(\mathrm{m}^{2} \cdot \mathrm{g}^{-1}\right)$ & Mean pore size $(\mathrm{nm})$ & Pore volume $\left(\mathrm{cm}^{3} \cdot \mathrm{g}^{-1}\right)$ & Lattice parameters $(\AA)$ \\
\hline BP-gel & 59 & 6.52 & 0.17 & 5.368 \\
$\mathrm{BP}$-td & 44 & 3.54 & 0.19 & 5.389 \\
$\mathrm{BP}-\mathrm{sr}$ & 62 & 3.78 & 0.13 & 5.407 \\
$\mathrm{~S}$-si & 339 & 0.53 & 0.29 & - \\
$\mathrm{S}$-iwi & 295 & 0.37 & 0.23 & - \\
$\mathrm{H}-\mathrm{ZSM}-5$ & 501 & 0.54 & 0.35 & - \\
$\mathrm{CeO}_{2}$ & - & - & - & 5.417 \\
\hline
\end{tabular}




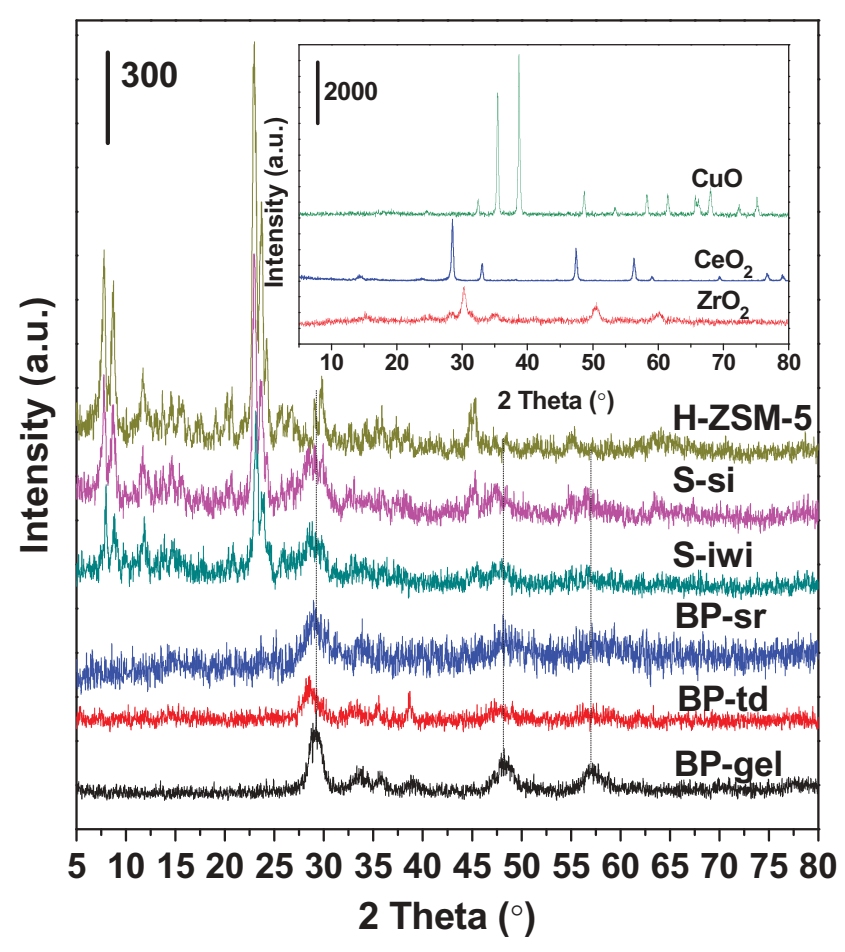

Figure 2. XRD patterns of $\mathrm{CuCe}_{0.75} \mathrm{Zr}_{0.25} \mathrm{O}_{\mathrm{y}}$ and $\mathrm{CuCe}_{0.75} \mathrm{Zr}_{0.25} \mathrm{O}_{\mathrm{y}} / \mathrm{H}-\mathrm{ZSM}-5$ catalysts.

\section{Temperature-programmed hydrogen reduction}

The reducibility of different $\mathrm{Cu}-\mathrm{Ce}-\mathrm{Zr}$ catalysts was investigated by $\mathrm{H}_{2}-\mathrm{TPR}$, and the curves and corresponding $\mathrm{H}_{2}$ consumption are given in Figure 3 and Table 2, respectively. The content of active components in the bulk-phase catalysts is higher than that in the supported catalysts, which is responsible for the high $\mathrm{H}_{2}$ consumption. In Figure 3, the broad peak of $\mathrm{H}_{2}$ consumption can be split into approximately four peaks $(\alpha, \beta, \gamma$, and $\delta$ ). The $\alpha$ peak at approximately $150-200^{\circ} \mathrm{C}$ is assigned to the well-dispersed copper oxide species strongly interacting with $\mathrm{CeO}_{2}$ (He et al., 2015b), while the reduction of $\mathrm{Cu}^{2+}$ ions in the $\mathrm{CeO}_{2}$ lattice is responsible for the $\beta$ peak at approximately $200-250^{\circ} \mathrm{C}$ (Dou et al., 2011). The $\gamma$ peak at approximately $250-300^{\circ} \mathrm{C}$ is due to the reduction of bulk-like $\mathrm{CuO}$ (Tang et al., 2015b). The $\delta$ peak at above $300^{\circ} \mathrm{C}$ is probably attributed to the reduction of $\mathrm{CeO}_{2}$ ( $\mathrm{He}$ et al., 2014). The broad peak of $\mathrm{H}_{2}$ consumption for the BP-td catalyst can be split into four peaks ( $\alpha, \beta, \gamma$, and $\delta$ ). In addition, the $\mathrm{H}_{2}$-TPR profile of the BP-gel catalyst is consistent with that of the BP-td catalyst, but all the peaks are shifted to lower temperatures. Such a phenomenon can be explained by the fact that a strong synergetic interaction between $\mathrm{CuO}$ and $\mathrm{CeO}_{2}$ can improve the mobility of the active oxygen species on the BP-gel catalyst surface, which is favorable for the redox cycle between $\mathrm{Cu}^{2+} / \mathrm{Cu}^{+}$and $\mathrm{Ce}^{3+} / \mathrm{Ce}^{4+}$ (Luo et al., 2007). Unlike the BP-gel and BP-td catalysts, three $\mathrm{H}_{2}$ consumption peaks $(\alpha, \beta$, and $\gamma)$ are examined for the $\mathrm{BP}$-sr catalyst, and the lack of a $\delta$ peak results in reduced $\mathrm{H}_{2}$ consumption $(1128 \mu \mathrm{mol} / \mathrm{g})$. The $\mathrm{H}_{2}$ consumption of the supported catalysts is lower than that of the bulk-phase catalysts (Table 2) due to a low amount of active component in the supported catalysts. The reduction peaks of the bulk-phase $\mathrm{CuCe}_{0.75} \mathrm{Zr}_{0.25} \mathrm{O}_{\mathrm{y}}$ catalysts and supported 


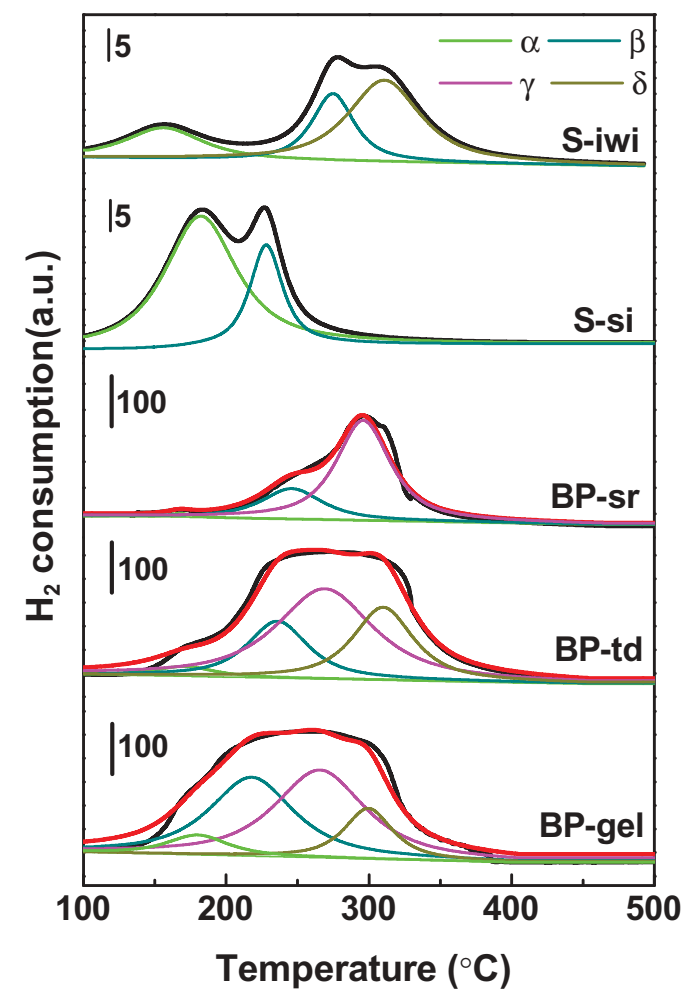

Figure 3. $\mathrm{H}_{2}$-TPR profiles of $\mathrm{CuCe}_{0.75} \mathrm{Zr}_{0.25} \mathrm{O}_{\mathrm{y}}$ catalysts and $\mathrm{CuCe}_{0.75} \mathrm{Zr}_{0.25} \mathrm{O}_{\mathrm{y}} / \mathrm{H}-\mathrm{ZSM}-5$ catalysts.

Table 2. $\mathrm{H}_{2}$ consumption of $\mathrm{CuCe}_{0.75} \mathrm{Zr}_{0.25} \mathrm{O}_{\mathrm{y}}$ and $\mathrm{CuCe}_{0.75} \mathrm{Zr}_{0.25} \mathrm{O}_{\mathrm{y}} / \mathrm{H}-\mathrm{ZSM}-5$ catalysts.

\begin{tabular}{lccccc}
\hline & \multicolumn{5}{c}{$\mathrm{H}_{2}$ consumption $\left(\mu \mathrm{mol}^{\circ} \mathrm{g}^{-1}\right)$} \\
\cline { 2 - 6 } Samples & a peak & $\beta$ peak & $\gamma$ peak & $\delta$ peak & Total \\
\hline BP-gel & 197 & 1128 & 1331 & 439 & 3096 \\
BP-td & 98 & 584 & 1469 & 741 & 2892 \\
BP-sr & 13 & 282 & 833 & - & 1128 \\
S-si & 125 & 39 & - & - & 164 \\
S-iwi & 33 & - & 39 & 72 & 144 \\
\hline
\end{tabular}

$\mathrm{CuCe}_{0.75} \mathrm{Zr}_{0.25} \mathrm{O}_{\mathrm{y}} / \mathrm{H}-\mathrm{ZSM}-5$ catalysts shift to lower temperatures compared with the reduction of $\mathrm{CuO}$ and $\mathrm{CeO}_{2}$ (Zhang et al., 2014). The shift toward lower temperatures may be partially caused by $\mathrm{Zr}^{4+}$ and $\mathrm{Cu}^{2+}$ ions inserting into the $\mathrm{CeO}_{2}$ lattice, which improves the mobility of the lattice oxygen and successively increases the lattice defects and oxygen vacancies (Zhou et al., 2014). The shift was probably also attributed to strong interactions between $\mathrm{CuO}$ and $\mathrm{CeO}_{2}$ in the $\mathrm{Cu}-\mathrm{Ce}-\mathrm{Zr}-\mathrm{O}$ solid solution that weaken the $\mathrm{Cu}-\mathrm{O}$ and $\mathrm{Ce}-\mathrm{O}$ chemical bonds (Bin et al., 2014).

\section{Temperature-programmed desorption of ammonia}

The $\mathrm{NH}_{3}$-TPD profiles of H-ZSM-5 and the synthesized catalysts are shown in Figure 4. Obvious differences in the acidity between the bulk-phase catalyst and the supported catalyst 


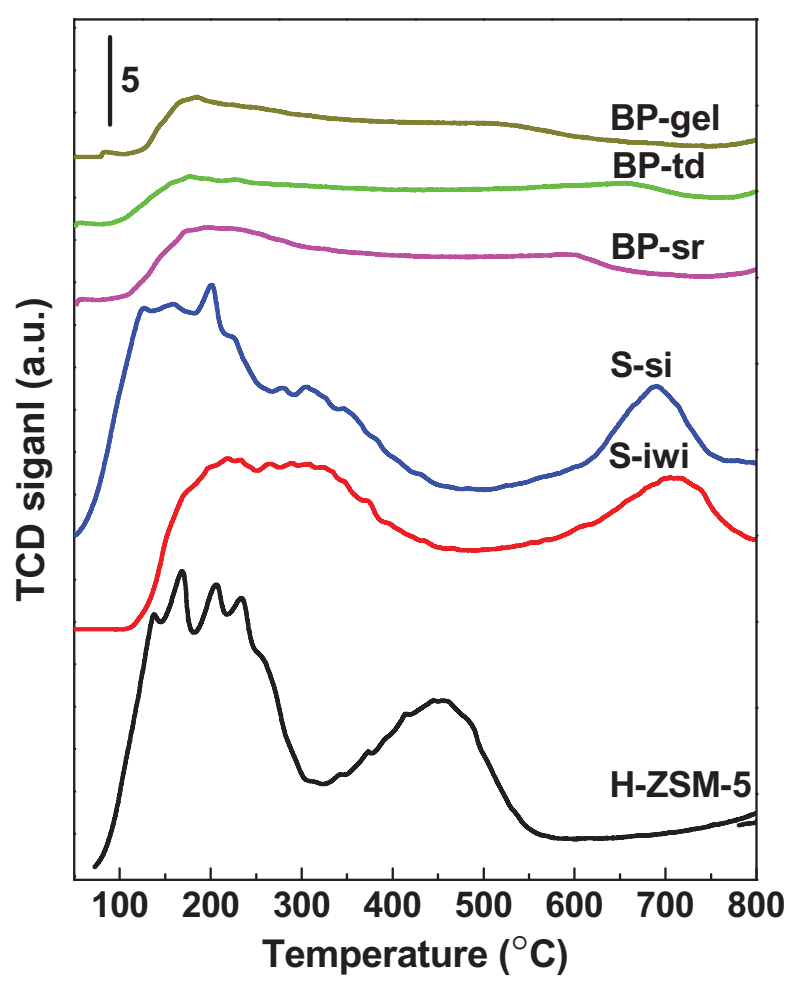

Figure 4. $\mathrm{NH}_{3}$-TPD profiles of $\mathrm{CuCe}_{0.75} \mathrm{Zr}_{0.25} \mathrm{O}_{\mathrm{y}}$ and $\mathrm{CuCe}_{0.75} \mathrm{Zr}_{0.25} \mathrm{O}_{\mathrm{y}} / \mathrm{H}-\mathrm{ZSM}-5$ catalysts.

are clearly observed, suggesting that the catalyst acidity primarily derives from H-ZSM-5. The $\mathrm{NH}_{3}$-TPD desorption peak of H-ZSM-5 exhibits a low-temperature peak caused by the physical adsorption of ammonia bound to $\mathrm{Si}-\mathrm{OH}$, and a high-temperature peak is also clearly seen due to $\mathrm{NH}_{3}$ adsorption on the strong acid sites of Si-OH-Al (Dou et al., 2011). As such, the $\mathrm{NH}_{3}$-TPD profiles of the supported catalysts exhibit two peaks corresponding to desorption at the weak acid sites and at the strong acid sites, but their intensities lower are than those of H-ZSM-5. Compared to the $\mathrm{NH}_{3}$-TPD desorption peak of H-ZSM-5, however, the high-temperature peak of the strong acid sites is observed to shift from $450^{\circ} \mathrm{C}$ to $700^{\circ} \mathrm{C}$ due to the generation of metal oxide nanoclusters after the introduction of copper, cerium and zirconium in the supported catalysts (Bin et al., 2014). Only one desorption peak located at approximately $200^{\circ} \mathrm{C}$ is clearly seen in the bulk-phase catalysts, as shown in Figure 4, which can be assigned to the physical adsorption of $\mathrm{NH}_{3}$ (Wang et al., 2015).

\section{Temperature-programmed desorption of oxygen}

It was previously reported that the change in oxygen species over a catalyst follows $\mathrm{O}_{2} \rightarrow \mathrm{O}_{2}^{-} \rightarrow \mathrm{O}^{-} \rightarrow \mathrm{O}^{2-}[4] . \mathrm{O}_{2}, \mathrm{O}_{2}^{-} / \mathrm{O}^{-}$and $\mathrm{O}^{2-}$ represent physically adsorbed oxygen, chemically adsorbed oxygen and lattice oxygen, respectively. The $\mathrm{O}_{2}$-TPD profiles of the synthesized catalyst are displayed in Figure 5, and the corresponding $\mathrm{O}_{2}$ adsorption content is provided in Table 3. Both adsorbed oxygen ( $\alpha$ peak) and lattice oxygen ( $\beta$ peak) are detected in all catalyst samples. However, it is clearly 


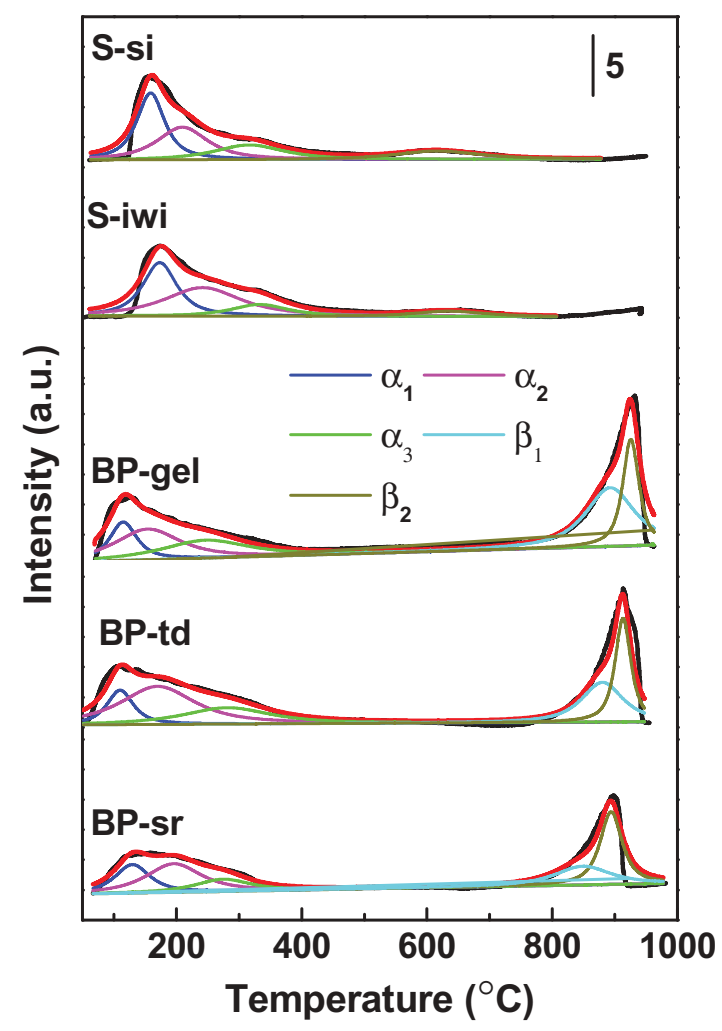

Figure 5. $\mathrm{O}_{2}$-TPD profiles of $\mathrm{CuCe}_{0.75} \mathrm{Zr}_{0.25} \mathrm{O}_{\mathrm{y}}$ catalysts and $\mathrm{CuCe}_{0.75} \mathrm{Zr}_{0.25} \mathrm{O}_{\mathrm{y}} / \mathrm{H}-\mathrm{ZSM}-5$ catalysts.

Table 3. $\mathrm{O}_{2}$-TPD data from $\mathrm{CuCe} \mathrm{e}_{0.75} \mathrm{Zr}_{0.25} \mathrm{O}_{\mathrm{y}}$ and $\mathrm{CuCe}_{0.75} \mathrm{Zr}_{0.25} \mathrm{O}_{\mathrm{y}} / \mathrm{H}-\mathrm{ZSM}-5$ catalysts.

\begin{tabular}{|c|c|c|c|c|c|c|}
\hline \multirow[b]{2}{*}{ Samples } & \multicolumn{6}{|c|}{$\mathrm{O}_{2}$ adsorption $\left(\mu \mathrm{mol} \cdot \mathrm{g}^{-1}\right)$} \\
\hline & $a_{1}-O_{2}$ & $a_{2}-O_{2}^{-}$ & $a_{3}-0^{-}$ & $\beta_{1}-0^{2-}$ & $\beta_{2}-0^{2-}$ & Total \\
\hline BP-gel & 6 & 12 & 9 & 17 & 10 & 54 \\
\hline BP-td & 5 & 17 & 8 & 10 & 10 & 50 \\
\hline BP-sr & 6 & 9 & 4 & 6 & 9 & 34 \\
\hline S-si & 11 & 10 & 6 & & & 32 \\
\hline S-iwi & 11 & 12 & 4 & & & 30 \\
\hline
\end{tabular}

*Represents lattice oxygen.

observed that the preparation method can greatly influence the amount of adsorbed oxygen and lattice oxygen.

Deconvolution of the broad $\alpha$ peak in Figure 5 produces three peaks $\left(\alpha_{1}, \alpha_{2}\right.$ and $\alpha_{3}$ ), where the $\alpha_{1}$ peak is the $\mathrm{O}_{2}$ desorption peak and the $\alpha_{2}$ and $\alpha_{3}$ peaks are the $\mathrm{O}_{2}{ }^{-}$ and $\mathrm{O}^{-}$desorption peaks, respectively (Luo et al., 2015, 2012). The $\beta$ peak located at $600^{\circ} \mathrm{C}$ is attributed to the desorption of $\mathrm{O}^{2-}$ (Zhang et al., 2015b). The $\beta_{1}$ peak can be ascribed to the release of surface lattice oxygen, while the $\beta_{2}$ peak is attributed to the desorption of bulk lattice oxygen due to the decomposition of copper oxide into metallic copper (Moretti et al., 2013). However, obvious differences between the locations of the $\alpha$ and $\beta$ peaks are clearly observed between the bulk-phase and the supported catalysts, especially the location of the $\beta$ peak. The intense synergistic 
effect between the active metal and support in the supported catalyst probably accounts for the shift in the $\beta$ peaks.

It is accepted from Table 3 that the BP-gel catalyst possesses the largest amount of lattice oxygen species among all the catalysts tested, which suggests the production of more oxygen vacancies (Zhang et al., 2015b). The presence of the oxygen vacancies in the catalyst could greatly enhance the catalytic activity as verified by the following catalyst test (see 3.6 section).

\section{Catalytic performance}

The toluene conversion and $\mathrm{CO}_{2}$ selectivity of the synthesized catalysts are shown in Figure 6 , and the corresponding $\mathrm{T}_{10}, \mathrm{~T}_{50}$, and $\mathrm{T}_{90}$ (temperature at which the VOC conversion is $10 \%, 50 \%$, and $90 \%$, respectively) values are listed in Table 4 . It is clearly seen in Figure 6 that the catalytic activity is closely related to the preparation method, and the activities are in following order: BP-gel $>\mathrm{S}$-si $>\mathrm{S}$-iwi $>\mathrm{BP}$-td $>\mathrm{BP}$-sr. The degraded toluene can be completely converted into $\mathrm{CO}_{2}$ and $\mathrm{H}_{2} \mathrm{O}$, while the $\mathrm{CO}_{2}$ selectivity synchronously increases with an increase in the toluene conversion.

With respect to the bulk-phase catalyst, BP-gel exhibits the highest activity compared with the other two catalysts, and $\mathrm{T}_{10}, \mathrm{~T}_{50}$ and $\mathrm{T}_{90}$ are $137^{\circ} \mathrm{C}, 183^{\circ} \mathrm{C}$ and $219^{\circ} \mathrm{C}$, respectively. At $260^{\circ} \mathrm{C}$, toluene was almost completely degraded, which is $80^{\circ} \mathrm{C}$ lower than the temperature for the BP-td catalyst. For the BP-sr catalyst, the toluene

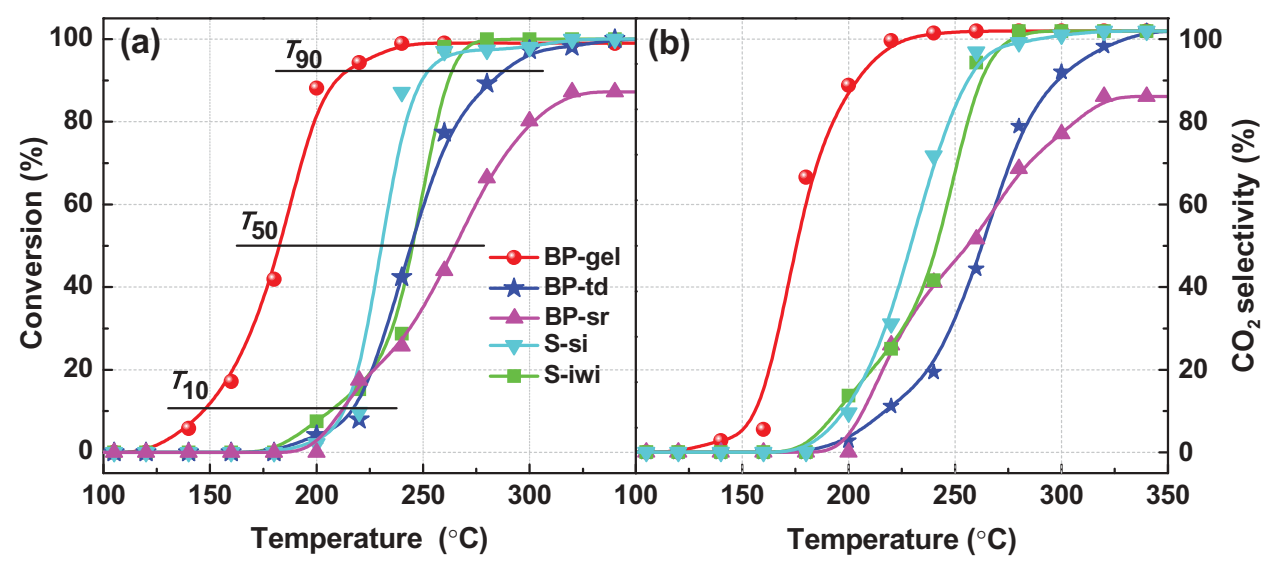

Figure 6. Toluene conversion (a) and $\mathrm{CO}_{2}$ selectivity (b) over $\mathrm{CuCe}_{0.75} \mathrm{Zr}_{0.25} \mathrm{O}_{\mathrm{y}}$ and $\mathrm{CuCe}_{0.75} \mathrm{Zr}_{0.25} \mathrm{O}_{\mathrm{y}} / \mathrm{H}$ ZSM-5 catalysts.

Table 4. $\mathrm{T}_{10}, \mathrm{~T}_{50}$ and $\mathrm{T}_{90}$ of $\mathrm{CuCe}_{0.75} \mathrm{Zr}_{0.25} \mathrm{O}_{\mathrm{y}}$ and $\mathrm{CuCe}_{0.75} \mathrm{Zr}_{0.25} \mathrm{O} \mathrm{\textrm {y }} / \mathrm{H}-\mathrm{ZSM}-5$ catalysts for toluene catalytic oxidation.

\begin{tabular}{lccc}
\hline Samples & $\mathrm{T}_{10}\left({ }^{\circ} \mathrm{C}\right)$ & $\mathrm{T}_{50}\left({ }^{\circ} \mathrm{C}\right)$ & $\mathrm{T}_{90}\left({ }^{\circ} \mathrm{C}\right)$ \\
\hline BP-gel & 137 & 183 & 219 \\
BP-td & 219 & 246 & 285 \\
BP-sr & 209 & 264 & - \\
S-si & 213 & 232 & 255 \\
S-iwi & 202 & 245 & 262 \\
\hline
\end{tabular}


conversion was only $87.2 \%$, although the temperature rose to $370^{\circ} \mathrm{C}$. A close relationship between the activity and the properties of the bulk-phase catalysts was obtained. Both the reducibility and oxygen vacancies of the catalysts are crucial favorable factors for the catalytic degradation of VOCs, and in this case, the effect of the surface area on the bulk-phase catalytic activity could be ignored. The highest activity of the BP-gel catalyst can be explained as follows. First, the BP-gel catalyst possesses excellent reducibility and more active oxygen species. Second, according to the XRD and $\mathrm{O}_{2^{-}}$ TPD results, the larger amount of oxygen vacancies presented in the BP-gel catalyst can promote the adsorption capacity of the $\mathrm{Cu}-\mathrm{Ce}-\mathrm{Zr}$ composite oxide catalysts for oxygen molecules (Delimaris \& Ioannides, 2009), which improves the formation of reactive oxygen species. Therefore, the catalytic activities are highly consistent with the oxygen content (intensity of the $\beta$ peaks) of the bulk-phase catalysts.

For the supported catalysts, the activity of S-si is slightly higher than that of the S-iwi catalyst. This should be ascribed to the fact that the S-si catalyst possesses larger amounts of finely dispersed $\mathrm{CuO}$ and lattice oxygen than the S-iwi sample. In addition, the larger surface area is also responsible for the higher activity of the S-si sample. The $\mathrm{T}_{50}$ and $\mathrm{T}_{90}$ of S-si are ca. $232^{\circ} \mathrm{C}$ and $255^{\circ} \mathrm{C}$, respectively, which are $13^{\circ} \mathrm{C}$ and $7^{\circ} \mathrm{C}$ lower than those of S-iwi sample.

BP-gel exhibits a better catalytic performance than that of the S-si catalyst during the catalytic oxidation of toluene, not only owning to the excellent reducibility and oxygen vacancies but also to the larger pore structure properties. The pore size of the BP-gel sample, which has a mesoporous structure, is $6.52 \mathrm{~nm}$, which is convenient for the migration and diffusion of toluene molecules $(6.0 \AA)$ (Bin et al., 2014). The prepared bulk-phase BP-gel only possesses fine mesopores, and the bulk-phase catalyst, with its porous structure, is more beneficial to the migration and diffusion of reactant molecules and further improves VOC degradation. In contrast, the microporous structure of S-si $(0.53 \mathrm{~nm})$ and $\mathrm{S}$-iwi $(0.37 \mathrm{~nm})$ restricts the migration and diffusion of toluene and thus reduces the activity. The activity of the supported catalysts is higher than that of the BP-td catalyst. This may be attributed to the larger amount of bulk $\mathrm{CuO}$ in the BP-td sample, which decreases the synergetic effect between $\mathrm{CuO}$ and $\mathrm{CeO}_{2}$ (Zou et al., 2009). For all the catalysts, no obvious relationships between the catalyst performances and the surface acidity were detected.

It is worth noting that the activity of the BP-gel catalyst toward toluene oxidation is superior to the reported catalysts. Moreover, the concentration of toluene in the present study is much higher than that reported in the literature (Deng et al., 2014), as displayed in Table 5. The $\mathrm{T}_{90}$ of the BP-gel catalyst is the lowest among the listed catalysts, which is only as low as $219^{\circ} \mathrm{C}$. Researchers have explored other supports to improve the activity of catalysts. Tang et al. (Tang et al., 2004) used different morphologies of nano- $\mathrm{CeO}_{2}$ as supports to prepare $\mathrm{La}_{0.8} \mathrm{Ce}_{0.2} \mathrm{MnO}_{3} / \mathrm{CeO}_{2}$ catalysts, and Lin et al. (Lin \& Bai, 2016) synthesized hollow

Table 5. Comparison of catalytic performance for toluene destruction over various catalysts.

\begin{tabular}{lrccl}
\hline Samples & \multicolumn{1}{c}{$\mathrm{SV}$} & Concentration $(\mathrm{ppm})$ & $\mathrm{T}_{90}\left({ }^{\circ} \mathrm{C}\right)$ & \multicolumn{1}{c}{ Reference } \\
\hline $\mathrm{CuCe}_{0.75} \mathrm{Zr}_{0.25} \mathrm{O}_{\mathrm{y}}$ & $24,000\left(\mathrm{~h}^{-1}\right)$ & 1500 & 219 & This work \\
$\mathrm{Cu}_{0.15} \mathrm{Ce}_{0.85} \mathrm{O}_{\mathrm{x}}$ & $36,000\left(\mathrm{~h}^{-1}\right)$ & 1000 & 231 & He et al. (2014) \\
$\mathrm{Mn}_{0.5} \mathrm{Ce}_{0.5}-\mathrm{HL}$ & $60,000(\mathrm{ml} \cdot \mathrm{g} / \mathrm{h})$ & 1000 & 245 & Tang et al., 2015 \\
$\mathrm{NiO}-\mathrm{CTAB}$ & $20,000\left(\mathrm{~h}^{-1}\right)$ & 1000 & 278 & Bai et al. (2013) \\
$0.3 \% \mathrm{Pd} / \mathrm{ZSM}-5$ & $26,000\left(\mathrm{~h}^{-1}\right)$ & 650 & 270 & He et al. (2010) \\
\hline
\end{tabular}




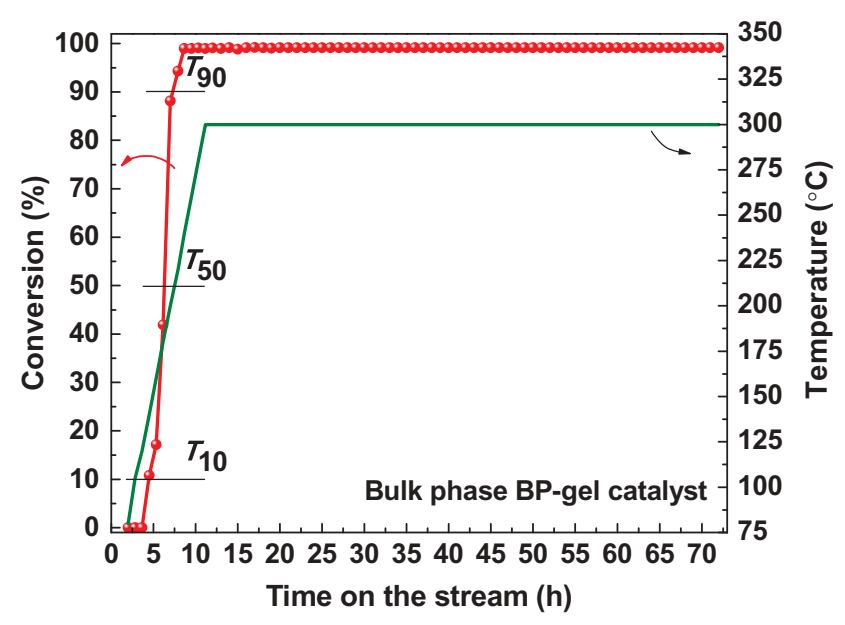

Figure 7. Stability of the bulk phase BP-gel catalyst as a function of time on stream.

and mesoporous $\mathrm{CoO}_{\mathrm{x}} / \mathrm{SiO}_{2}$ spheres as a supported catalyst. Although the activities of the $\mathrm{La}_{0.8} \mathrm{Ce}_{0.2} \mathrm{MnO}_{3} / \mathrm{CeO}_{2}$ and $\mathrm{CoO}_{\mathrm{x}} / \mathrm{SiO}_{2}$ catalysts are higher than that of the S-si catalyst, the activities are lower than that of the $\mathrm{BP}$-gel catalyst in this study, and $\mathrm{T}_{90}$ for $\mathrm{La}_{0.8} \mathrm{Ce}_{0.2} \mathrm{MnO}_{3} /$ $\mathrm{CeO}_{2}$ was $240^{\circ} \mathrm{C}$, which is higher than that of the BP-gel catalyst $\left(219^{\circ} \mathrm{C}\right)$.

To evaluate the stability of the BP-gel catalyst, the reaction temperature for toluene oxidation was set at $300^{\circ} \mathrm{C}$, since toluene was almost completely degraded over the bulk-phase BP-gel catalyst at $260^{\circ} \mathrm{C}$ (Figure 6). In Figure 7, the toluene conversion was almost maintained above 99\% during testing for $72 \mathrm{~h}$, and no deactivation was observed. The obtained result demonstrates that the stability of the BP-gel catalyst is excellent. The introduction of $\mathrm{ZrO}_{2}$ in the bulkphase catalyst should be responsible for such stability (Riva et al., 2009).

\section{Conclusions}

Different bulk-phase catalysts, $\mathrm{CuCe}_{0.75} \mathrm{Zr}_{0.25} \mathrm{O}_{\mathrm{y}}$, and supported catalysts, $\mathrm{CuCe}_{0.75} \mathrm{Zr}_{0.25} \mathrm{O}_{\mathrm{y}} / \mathrm{H}-\mathrm{ZSM}-5$, were successfully prepared, and the catalytic activities toward toluene oxidation were investigated in a fixed-bed reactor. The catalysts were comprehensively studied by BET, XRD, $\mathrm{O}_{2}$-TPD, $\mathrm{NH}_{3}$-TPD and $\mathrm{H}_{2}$-TPR to elucidate their structural properties, reducibility and oxygen vacancies. The characterizations were also correlated to the catalytic performances to investigate the structure-property relationships. The results showed that the performance and structure of the $\mathrm{Cu}-\mathrm{Ce}-\mathrm{Zr}$ catalysts were closely associated with the preparation method. The bulk-phase BP-gel catalyst prepared by the sol-gel method exhibited the highest activity because its mesoporous structure with large mean pore sizes was beneficial for the mass transfer of reactant molecules and the convenient migration and diffusion of VOCs. In addition, the good low-temperature reducibility and rich oxygen vacancies of the BP-gel catalyst also enhanced the catalytic performances for toluene oxidation. Furthermore, the temperature of complete conversion was $260^{\circ} \mathrm{C}$, and no deactivation phenomenon was observed during stability testing at $300^{\circ} \mathrm{C}$ for $72 \mathrm{~h}$. 


\section{Funding}

We gratefully acknowledge financial support from the National Natural Science Foundation of China (Numbers 51776216, 51736010), and the Science Foundation of the Chinese Academy of Sciences (LHD2017QN05).

\section{References}

Bai, G.M., Dai, H.X., Deng, J.G., Liu, Y.X., Qiu, W.G., Zhao, Z.X., Li, X.W., and Yang, H.G. 2013. The microemulsion preparation and high catalytic performance of mesoporous $\mathrm{NiO}$ nanorods and nanocubes for toluene combustion. Chem. Eng. J., 219, 200-208.

Bin, F., Song, C.L., Lv, G., Song, J.O., Wu, S.H., and Li, X.D. 2014. Selective catalytic reduction of nitric oxide with ammonia over zirconium-doped copper/ZSM-5 catalysts. Appl. Catal. B: Environ., 150-151, 532-543.

Chen, H.H., Zhang, H.P., and Yan, Y. 2014. Fabrication of porous copper/manganese binary oxides modified ZSM-5 membrane catalyst and potential application in the removal of VOCs. Chem. Eng. J., 254, 133-142.

Delimaris, D., and Ioannides, T. 2009. VOC oxidation over $\mathrm{CuO}-\mathrm{CeO}_{2}$ catalysts prepared by a combustion method. Appl. Catal. B: Environ., 89, 295-302.

Deng, Q.F., Ren, T.Z., Agula, B., Liu, Y.P., and Yuan, Z.Y. 2014. Mesoporous $\mathrm{CexZr}_{1-\mathrm{x}} \mathrm{O}_{2}$ solid solutions supported $\mathrm{CuO}$ nanocatalysts for toluene total oxidation. J. Ind. Eng. Chem., 20, 3303-3312.

Dou, B.J., Hu, Q., Li, J.J., Qiao, S.Z., and Hao, Z.P. 2011. Adsorption performance of VOCs in ordered mesoporous silicas with different pore structures and surface chemistry. J. Hazard. Mater., 186, 1615-1624.

Ge, T.G., Hua, Z.L., He, X.Y., Zhu, Y., Ren, W.C., Chen, L.S., Zhang, L.X., Chen, H.G., Liu, C.C., Yao, H.L., and Shi, J.L. 2015. One-pot synthesis of hierarchically structured ZSM-5 zeolites using single micropore-template. Chin. J. Catal, 36, 866-873.

Gutiérrez-Ortiz, J.I., Rivas, B.D., López-Fonseca, R., and Gonzālez-Velasco, J.R. 2006. Catalytic purification of waste gases containing VOC mixtures with $\mathrm{Ce} / \mathrm{Zr}$ solid solutions. Appl. Catal. B: Environ., 65, 191-200.

He, C., Li, P., Cheng, J., Hao, Z.P., and Xu, Z.P. 2010. A comprehensive study of deep catalytic oxidation of benzene, toluene, ethyl acetate, and their mixtures over Pd/ZSM-5 catalyst: mutual effects and kinetics. Water Air Soil Pollut., 209, 365-376.

He, C., Xu, B.T., Shi, J.W., Qiao, N.L., Hao, Z.P., and Zhao, J.L. 2015a. Catalytic destruction of chlorobenzene over mesoporous $\mathrm{ACeO}_{x}(\mathrm{~A}=\mathrm{Co}, \mathrm{Cu}, \mathrm{Fe}, \mathrm{Mn}$, or $\mathrm{Zr})$ composites prepared by inorganic metal precursor spontaneous precipitation. Fuel Process. Tech., 130, 179-187.

He, C., Yu, Y.K., Shi, J.W., Shen, Q., Chen, J.S., and Liu, H.X. 2015b. Mesostructured Cu-mn-Ce-O composites with homogeneous bulk composition for chlorobenzene removal: Catalytic performance and microactivation course. Mater. Chem. Phys., 157, 87-100.

He, C., Yu, Y.K., Yue, L., Qiao, N.L., Li, J.J., Shen, Q., Yu, W.J., Chen, J.S., and Hao, Z.P. 2014. Lowtemperature removal of toluene and propanal over highly active mesoporous $\mathrm{CuCeO}_{x}$ catalysts synthesized via a simple self-precipitation protocol. Appl. Catal. B: Environ., 147, 156-166.

$\mathrm{Hu}$, C.Q., Zhu, Q.S., and Jiang, Z. 2009. Nanosized $\mathrm{CuO}-\mathrm{zr}_{x} \mathrm{Ce}_{1-x} \mathrm{O}_{\mathrm{y}}$ aerogel catalysts prepared by ethanol supercritical drying for catalytic deep oxidation of benzene. Powder Tech., 194, $109-114$.

Jia, A.P., Hu, G.S., Meng, L., Xie, Y.L., Lu, J.Q., and Luo, M.F. 2012. CO oxidation over $\mathrm{CuO} / \mathrm{Ce}_{1-x} \mathrm{Cu}_{x} \mathrm{O}_{2-\delta}$ and $\mathrm{Ce}_{1-x} \mathrm{Cu}_{x} \mathrm{O}_{2-\delta}$ catalysts: synergetic effects and kinetic study. J. Catal, 289, 199-209.

Kuo, C.P., Liao, H.T., Chou, C.C.K., and Wu, C.F. 2014. Source apportionment of particulate matter and selected volatile organic compounds with multiple time resolution data. Sci. Total. Environ., 472, 880-887.

Li, S.M., Hao, Q.L., Zhao, R.Z., Liu, D.L., Duan, H.Z., and Dou, B.J. 2016. Highly efficient catalytic removal of ethyl acetate over Ce/Zr promoted copper/ZSM-5 catalysts. Chem. Eng. J., 285, 536-543. 
Lin, L.Y. and Bai, H.L. 2016. Salt-induced formation of hollow and mesoporous CoOx/SiO2 spheres and their catalytic behavior in toluene oxidation. RSC Adv, 6, 24304-24313.

Lu, H.F., Kong, X.X., Huang, H.F., Zhou, Y., and Chen, Y.F. 2015. Cu-mn-ce ternary mixed-oxide catalysts for catalytic combustion of toluene. J. Environ. Sci., 32, 102-107.

Luo, J.J., Xua, H.Y., Liu, Y.F., Chu, W., Jiang, C.F., and Zhao, X.S. 2012. A facile approach for the preparation of biomorphic $\mathrm{CuO}-\mathrm{ZrO}_{2}$ catalyst for catalytic combustion of methane. Appl. Catal. A: Gen., 423-424, 121-129.

Luo, M.F., Ma, J.M., Lu, J.Q., Song, Y.P., and Wang, Y.J. 2007. High-surface area $\mathrm{CuO}_{-} \mathrm{ceO}_{2}$ catalysts prepared by a surfactant-templated method for low-temperature $\mathrm{CO}$ oxidation. $J$. Catal, 246, 52-59.

Luo, Y.J., Qian, Q.R., and Chen, Q.H. 2015. On the promoting effect of the addition of $\mathrm{Ce}_{\mathrm{x}} \mathrm{Zr}_{1-\mathrm{x}} \mathrm{O}_{2}$ to palladium based alumina catalysts for methanol deep oxidation. Mater. Res. Bull., 36, 866-873.

Moretti, E., Lenarda, M., Riello, P., Storaro, L., Talon, A., and Frattini, R. 2013. Influence of synthesis parameters on the performance of $\mathrm{CeO}_{2}-\mathrm{CuO}$ and $\mathrm{CeO}_{2}-\mathrm{ZrO}_{2}-\mathrm{CuO}$ systems in the catalytic oxidation of CO in excess of hydrogen. Appl. Catal. B: Environ., 129, 556-565.

Moretti, E., Molina, A.I., Sponchia, G., Talon, A., Frattini, R., Rodriguez-Castellon, E., and Storaro, L. 2017. Low-temperature carbon monoxide oxidation over zirconia-supported $\mathrm{CuO}-\mathrm{CeO}_{2}$ catalysts: effect of zirconia support properties. Appl. Surf. Sci., 403, 612-622.

Riva, B.D., Pez-Fonseca, R.L., Sampedro, C., and Gutiérrez-Ortiz, J.I. 2009. Catalytic behaviour of thermally aged $\mathrm{Ce} / \mathrm{Zr}$ mixed oxides for the purification of chlorinated VOC-containing gas streams. Appl. Catal. B: Environ., 90, 545-555.

Tang, W.X., Li, W.H., Shan, X., Wu, X.F., and Chen, Y.F. 2015a. Template-free synthesis of hierarchical layer-stacking $\mathrm{CeO}_{2}$ nanostructure with enhanced catalytic oxidation activity. Mater. Lett., 140, 95-98.

Tang, W.X., Wu, X.F., Liu, G., Li, S.D., Li, D.Y., Li, W.H., and Chen, Y.F. 2015b. Preparation of hierarchical layer-stacking Mn-Ce composite oxide for catalytic total oxidation of VOCs. J. Rare Earth, 33, 62-69.

Tang, X.L., Zhang, B.C., Li, Y., Xu, Y.D., Xin, Q., and Shen, W.J. 2004. Carbon monoxide oxidation over $\mathrm{CuO} / \mathrm{CeO}_{2}$ catalysts. Catal. Today, 93-95, 191-198.

Wang, J., Yunus, R., Li, J., Li, P., Zhang, P., and Kim, J. 2015a. In situ synthesis of manganeseoxides on polyester fiber for formaldehyde decomposition at room temperature. Appl. Surf. Sci., 357, 787-794.

Wang, Z., Qu, Z.P., and Fan, R. 2015b. The Al promotional effect for $\mathrm{Ce}_{0.4} \mathrm{Zr}_{0.6} \mathrm{O}_{2}$ mixed oxides in selective catalytic oxidation of ammonia to nitrogen. Sep. Purif. Tech., 147, $24-31$.

Zhang, L.F., He, Y.C., Yang, X.J., Yuan, H., Du, Z.P., and Wu, Y.X. 2015a. Oxidative carbonylation of phenol to diphenyl carbonate by $\mathrm{Pd} / \mathrm{MO}-\mathrm{MnFe}_{2} \mathrm{O}_{4}$ magnetic catalyst. Chem. Eng. J., 278, 129-133.

Zhang, Q.L., Xu, L.S., Ning, P., Gu, J.J., and Guan, Q.Q. 2014. Surface characterization studies of $\mathrm{CuO}-\mathrm{CeO}_{2}-\mathrm{ZrO}_{2}$ catalysts for selective catalytic reduction of $\mathrm{NO}$ with $\mathrm{NH}_{3}$. Appl. Surf. Sci., 317, 955-961.

Zhang, Z.X., Jiang, Z., and Shangguan, W.F. 2015b. Low-temperature catalysis for VOCs removal in technology and application: a state-of-the-art review. Catal. Today, 264, 270-278.

Zhou, G.L., Lan, H., Gao, T.T., and Xie, H.M. 2014. Influence of Ce/Cu ratio on the performance of ordered mesoporous $\mathrm{CeCu}$ composite oxide catalysts. Chem. Eng. J., 246, 53-63.

Zou, Z.Q., Meng, M., Zha, Y.Q., Zou, Z.Q., Meng, M., and Zha, Y.Q. 2009. The effect of dopant Cu, $\mathrm{Fe}, \mathrm{Ni}$ or $\mathrm{La}$ on the structures and properties of mesoporous Co-Ce-O compound catalysts. J. Alloy. Compd., 470, 96-106. 